\title{
Efek Kombinasi Ekstrak Etanol Acalypha indica dan Centella asiatica pada Jantung Tikus Pascahipoksia: Gen Hif-1a, Troponin I dan Stres Oksidatif
}

Penulis

Afiliasi
Marsetyo Edhiatmi ${ }^{1}$, Wawaimuli Arozal ${ }^{2}$, Erni H Purwaningsih ${ }^{3}$

${ }^{1}$ Departemen Pendidikan Kedokteran, Fakultas Kedokteran, Universitas Indonesia, Indonesia.
2 Departemen Farmakologi \& Teraupetik, Fakultas Kedokteran, Universitas Indonesia, Indonesia.
${ }^{3}$ Departemen Ilmu Farmasi Kedokteran, Fakultas Kedokteran, Universitas Indonesia, Indonesia.

\section{Kata Kunci \\ $\rightarrow$ Acalypha indica \\ - Centella asiatica \\ ? hipoksia \\ $\rightarrow$ HIF-1a \\ $\rightarrow \mathrm{MDA}$ \\ $\rightarrow$ SOD}

Diterima 7 September 2015 Direvisi 25 Desember 2015 Disetujui 20 April 2016

*Penulis korespondensi Marsetyo Edhiatmi Pendidikan Kedoketran, FK Universitas Indoneisa emi.akbar@gmail.com

\section{Abstrak}

Hipoksia meningkatkan pembentukan dan pelepasan spesies oksigen reaktif (ROS). Sel mempunyai mekanisme melindungi diri terhadap kerusakan akibat pembentukan ROS yang terjadi secara alami. Jika pembentukan radikal bebas terjadi berlebihan maka dapat menyebabkan stres oksidatif yang memicu kerusakan sel terutama pada jantung. Sehingga tubuh memerlukan asupan antioksidan. Acalypha indica dan Centella asiatica terbukti memiliki efek antioksidan dan melindungi banyak organ dari kondisi hipoksia, sehingga penelitian ini dilakukan dengan tujuan untuk mengetahui efek antioksidan kombinasi ekstrak etanol Acalypha indica dan Centella asiatica pada organ jantung tikus Spraque-Dawley pascahipoksia. Tiga puluh lima ekor tikus Sprague-Dawley jantan diinduksi hipoksia selama 7 hari dalam ruang khusus, kemudian diberi perlakuan. Ekstrak Acalypha indica, ekstrak Centella asiatica dan kombinasinya diberikan kepada kelompok tikus yang telah dibagi menjadi grup A (hipoksia dan diberi air), B (hipoksia dan diberi kombinasi Acalypha indica $200 \mathrm{mg} / \mathrm{kgBB}$ dan Centella asiatica $150 \mathrm{mg} / \mathrm{kgBB}$ ), C (hipoksia dan diberi kombinasi Acalypha indica $250 \mathrm{mg} / \mathrm{kgBB}$ dan Centella asiatica $100 \mathrm{mg} / \mathrm{kgBB}$ ), D (hipoksia dan diberi Acalypha indica $250 \mathrm{mg} / \mathrm{kgBB}$ ), E (hipoksia dan diberi Centella asiatica $150 \mathrm{mg} / \mathrm{kgBB}$ ), $\mathrm{F}$ (hipoksia dan diberi vitamin C 100mg/kgBB) dan kelompok normal. Perlakuan diberikan secara oral selama 7 hari setelah hipoksia. Parameter yang diamati adalah ekspresi mRNA HIF-1 $\alpha$, kadar MDA, aktivitas enzim SOD dan ekspresi mRNA cTnI. Tidak terdapat perbedaan bermakna pada ekspresi HIF-1 $\alpha$ antara grup A dan kelompok tikus normal $(p>0,05)$. Kadar MDA meningkat signifikan pada grup $A(p<0,05)$ dibanding tikus normal. Kadar MDA grup $D$ mengalami penurunan secara signifikan $(p<0,05)$ dibanding grup $A$. Aktivitas SOD menurun signifikan pada grup $A(p<0,05)$ dibanding tikus normal. Aktivitas SOD grup $B$ dan $E(p<0,05)$ mengalami peningkatan secara signifikan dibanding grup A. Grup B meningkat signifikan $(p<0,05)$ dibanding grup E. Tidak terdapat perbedaan bermakna antar kelompok perlakuan pada Ekspresi cTnl. Tidak terdapat korelasi antara kadar MDA dan aktivitas SOD serta ekspresi mRNA HIF-1a dan mRNA cTnl. Pemberian kombinasi ekstrak Acalypha indica dan Centella asiatica tidak dapat membantu memproteksi kerusakan jantung pascahipoksia. 
Pendahuluan

Kondisi hipoksia pada organ jantung dapat membahayakan fungsi miokardium. Hipoksia adalah keadaan patologis di dalam tubuh atau bagian dari tubuh (jaringan atau sel) yang disebabkan kurang adekuatnya asupan oksigen. Hipoksia meningkatkan pembentukan dan pelepasan reactive oxygen species (ROS) dari dalam mitokondria. Spesies radikal bebas ini menyebabkan peroksidasi lipid dan efek delesi lain pada struktur sel. Salah satu senyawa produk dari reaksi peroksidasi lipid yang digunakan sebagai marker (petanda) terjadinya stres oksidatif adalah malondialdehid. Jika hipoksia tidak dihilangkan, kerusakan fungsi mitokondria dan peningkatan permeabilitas membran dapat menyebabkan kerusakan morfologi sel (Enikarmila et al. 2009; Richard et al. 2010; Septelia et al. 2009).

Salah satu respons sel terhadap kondisi hipoksia adalah peningkatan kadar protein Hypoxia-inducible factor-1 (HIF-1). HIF-1 terdiri atas subunit $\beta$ yang diekspresikan secara terus-menerus dan subunit $\alpha$ yang diregulasi oleh oksigen. Ekspresi HIF-1 $\alpha$ meningkat secara nyata pada kondisi hipoksia. HIF-1 $\alpha$ yang dihidroksilasi oleh PHD mengikat protein von Hippel Lindau (pVHL), selanjutnya diubiquitinasi (Ub) dan akhirnya terdegradasi oleh 26S-proteasome. Pada kondisi hipoksia atau kelebihan nitrat oksida (NO) atau superoksida dapat menghambat PHD sehingga HIF-1 $\alpha$ menjadi stabil. Telah dibuktikan bahwa peningkatan ekspresi HIF-1 $\alpha$ pada organ jantung mencapai maksimum pada hari ke tujuh dan tetap intensif dipertahankan sampai hari ke 21 (Bemhard et al. 2007; Enikarmila et al. 2009; Septelia et al. 2009).

Antioksidan merupakan perlindungan terhadap kelebihan radikal bebas yang mudah dioksidasi dan dapat menetralkan sebagian besar radikal bebas tersebut. Antioksidan yang penting diantaranya adalah enzim alamiah termasuk glutathion peroxidase, Superoxyde Dismutase dan katalase, serta vitamin A, C, dan E (Scott \& Meg 2008). Pengobatan untuk mengatasi kerusakan organ seringkali kurang bermanfaat dan menimbulkan efek samping obat, sehingga diperlukan alternatif berupa pemanfaatan tanaman berkhasiat antioksidan terhadap perbaikan sel miosit jantung.

Sifat antioksidan juga dapat ditemukan pada tanaman yang telah banyak diteliti di antaranya adalah akar Acalypha indica dan Centella asiatica (Pooja et al. 2014; Vasantharuba et al. 2012; Sanseera et al. 2012;
Anirban et al. 2013). Penelitian pendahuluan oleh Farida,dkk (Farida et al. 2010). bahwa kombinasi ekstrak air akar Acalypha indica 200 mg/kgBB dengan Centella asiatica $150 \mathrm{mg} / \mathrm{kgBB}$ menunjukkan efek terapi pada hipoksia otak berupa perbaikan jumlah sel normal, kondensasi khromatin nukleus dan piknotik sel lapis luar girus dentatus hipokampus. Pada dosis Acalypha indica $250 \mathrm{mg} / \mathrm{kgBB}$ dan Centella asiatica 150 $\mathrm{mg} / \mathrm{kgBB}$ juga menunjukkan perbaikan namun tidak sebaik kombinasi ekstrak air Acalypha indica 200 mg/kgBB dengan Centella asiatica 150 mg/kgBB yang kemungkinan disebabkan karena peningkatan efek vasodilator oleh Centella asiatica, sehingga dosis Centella asiatica perlu diturunkan. Sampai saat ini belum ada bukti ilmiah yang menunjukkan bahwa kombinasi ekstrak etanol Acalypha indica dan Centella asiatica pada dosis tertentu dapat memperbaiki kerusakan jaringan jantung pascahipoksia. Secara in vitro, kombinasi ke dua ekstrak tersebut juga belum terbukti menunjukkan efek antioksidan yang lebih baik dibandingkan dengan efek antioksidan ekstrak Acalypha indica atau Centella asiatica yang diberikan secara tunggal maupun dengan antioksidan kuat yaitu vitamin $\mathrm{C}$.

Tujuan penelitian ini adalah untuk melihat efek kombinasi ekstrak etanol Acalypha indica (Al) dan Centella asiatica (CA) pada organ jantung tikus Sprague-Dawley pascahipoksia, fokus pada efek antioksidan dan kerusakan otot jantung melalui pemeriksaan malondialdehid (MDA), Superoxyde dismutase (SOD), ekspresi mRNA HIF-1 $\alpha$ dan mRNA cardiac Troponin I (cTnI).

\section{Metode Penelitian}

Penelitian dilakukan pada tiga puluh lima (35) ekor tikus jantan galur Spraque Dawley usia 10-12 minggu, dengan berat badan 150-250 gram yang diperoleh dari Pusat Penelitian dan Pengembangan Kesehatan Kemenkes RI. Selama eksperimen seluruh hewan coba diadaptasi di kandang hewan Dep. Biokimia, dengan suhu dan kelembaban ruangan yang konstan, penerangan yang cukup serta diberi makan dan minum bebas selama satu minggu sebelum perlakuan. Hewan coba dibagi menjadi tujuh kelompok. Induksi hipoksia dilakukan dengan memasukkan tikus ke dalam kandang khusus hipoksia (makan dan minum bebas) yang dialiri gas $\mathrm{N}_{2} 90 \%$ dan $10 \%$ gas $\mathrm{O}_{2}$ selama seminggu. Kondisi tikus dikontrol setiap hari. Konfirmasi tikus hipoksia dilakukan dengan 
pengambilan darah arteri untuk diperiksa analisis gas darah. Pemeriksaan dilakukan di laboratorium Patologi Klinik RSCM. Setelah induksi hipoksia selama seminggu dilakukan reoksigenasi selama 2 jam. Selama satu minggu berikutnya setiap kelompok diberi perlakuan setiap hari selama 7 hari. Tikus dibagi secara acak ke dalam 7 kelompok: 1) Tikus normal; 2) Kontrol negatif hanya diberi air; 3) Kombinasi ekstrak Al 200 $\mathrm{mg} / \mathrm{kgBB}+\mathrm{CA} 150 \mathrm{mg} / \mathrm{kgBB}$; 4) Kombinasi Al 250 $\mathrm{mg} / \mathrm{kgBB}+\mathrm{CA} 100 \mathrm{mg} / \mathrm{kgBB}$; 5) Ekstrak Al $250 \mathrm{mg} / \mathrm{kgBB}$; 6) Ekstrak CA $150 \mathrm{mg} / \mathrm{kgBB}$;

\section{Pengukuran MDA}

Pengukuran kadar MDA, digunakan homogenat jantung (50-100 mg jaringan jantung dalam PBS 0,1 M $\mathrm{pH} 7,2$ ) dan plasma. Homogenat yang sudah diencerkan ditambah asam trikarboksilat $10 \%$ untuk mengendapkan protein, kemudian dilakukan sentrifugasi $5000 \mathrm{rpm}$ selama 10 menit. Supernatan diambil dan dipindahkan, kemudian ditambahkan TBA $0,67 \%$ dan diinkubasi pada suhu 96 ㄷ c selama 10 menit. Dinginkan pada suhu ruang. Serapan diukur pada panjang gelombang $530 \mathrm{~nm}$ dibandingkan dengan serapan standar MDA dengan konsentrasi 0; 0,3125; 0,$625 ; 1,25 ; 2,5$ dan 3,75 nmol/mL. Pemeriksaan MDA dilakukan secara duplo. Kadar MDA dinyatakan dalam satuan nmol/mg jaringan jantung (Jusman 2010).

\section{Ekspresi HIF-1 $\alpha$ dan cTnI}

Ekspresi HIF-1 $\alpha$ jantung dilakukan melalui analisis relatif mRNA HIF- $1 \alpha$ dengan cara isolasi RNA, Pengukuran konsentrasi dilakukan dengan meggunakan Spektrofotometer pada $\lambda 260 \mathrm{~nm}$ dan $280 \mathrm{~nm}$ untuk menilai kemurnian RNA. Amplifikasi cDNA dengan menggunakan alat Real Time PCR. Dengan Real Time PCR dapat ditentukan jumlah salinan CDNA hasil amplifikasi yang menggambarkan ekspresi gen HIF-1 $\alpha$ secara kuantitatif. Gen $\beta$ Actin digunakan sebagai standar eksternal. Amplifikasi gen $\beta$ Actin dilakukan dengan kondisi yang sama dengan gen HIF-1 $\alpha$. Dengan Real Time PCR diperoleh nilai efisiensi dan Cycle Threshold/C(t). Analisis ekspresi gen dinilai secara "relative quantification" sehingga diperoleh nilai kadar relatif mRNA, dengan menggunakan metode Livax (Livak 2001).

\section{Pemeriksaan aktivitas enzim Superoxide Dismutase (SOD)}

Aktivitas SOD ditentukan secara biokimia sesuai metode Misra dan Fridovich (Misra \& Fridovich 1972) dengan cara mengukur hambatan auto oksidasi epinefrin menjadi adenokrom dalam $\mathrm{pH}$ basa $(\mathrm{pH} 10,2)$ dan diukur serapannya pada panjang gelombang 480 $\mathrm{nm}$. SOD dinyatakan dalam unit/mg protein.

\section{Analisis Data}

Data ekspresi mRNA HIF-1 $\alpha$, kadar MDA, aktivitas enzim SOD, dan ekspresi cardiac troponin I (cTnl) yang diperoleh dianalisis dengan uji one way ANOVA diikuti dengan analisis post-hoc dimana perbedaan dianggap bermakna secara statistik bila $p<0,05$. Jika distribusi dan varians data tidak normal maka dilakukan transformasi data dahulu namun bila tetap tidak normal analisis data menggunakan uji Kruskal Wallis dilanjutkan dengan analisis post-hoc Mann whitney. Melakukan uji korelasi Pearson antara data MDA dan SOD serta antara data mRNA HIF-1 $\alpha$ dan mRNA cTnl.

\section{Hasil Penelitian}

Seluruh tikus tidak mengalami perubahan berat badan yang bermakna selama induksi hipoksia dan perlakuan.

\section{Perubahan ekspresi mRNA HIF-1a}

Hasil analisis statistik ekspresi mRNA HIF-1 $\alpha$ diperoleh peningkatan bermakna antar kelompok perlakuan $(p<0,05)$. Kelompok $B, C, D, E$ dan $F$

Tabel 1. Susunan Basa Primer

\begin{tabular}{lll}
\hline HIF-1 $\alpha$ & Forward & 5'-AATCCATTTTCAGCTCAGGAC-3' \\
& Reverse & 5'-GGCAGTGACAGTGATGGTAGG-3' \\
cTnl & Forward & 5'-TTGAAGAGCTTCAGGACCTA-3' \\
& Reverse & 5'-CAGTGATGTTCTTGGTGACT-3' \\
B-aktin & Forward & 5'-TGTTGTCCCTGTATGCCTCT-3' \\
& Reverse & 5'-TAATGTCACGCACGATTTCC-3' \\
\hline
\end{tabular}


didapatkan perbedaan tidak bermakna dibanding kelompok $A(p>0,05)$. Terdapat peningkatan bermakna pada kelompok $D, E$ dan $F$ dibanding kelompok $B$ $(p<0,05)$ serta antara kelompok $E$ dibanding kelompok C.

\section{Aktivitas Enzim SOD dan Kadar MDA Jantung}

Rasio aktivitas enzim SOD dan kadar MDA jantung dihitung dengan membagi seluruh kelompok perlakuan dengan kelompok kontrol sehingga didapatkan grafik sesuai gambar 3 dan 4. Hasil analisis statistik rasio aktivitas enzim SOD didapatkan peningkatan bermakna antara kelompok $B(p=0,000)$ dan $E(p=0,010)$ dibanding kelompok A. Kelompok $C$ $(p=0,000), D(p=0,000), E(p=0,000)$ dan $F$ terjadi penurunan yang bermakna dibanding kelompok $B$.
Kelompok B $(p=0,000)$ dan $E(p=0,004)$ meningkat secara bermakna dibanding kelompok F. Dari data rasio kadar MDA jantung dibanding kontrol dilakukan uji kemaknaan Kruskal Wallis. Hasil analisis statistik rasio kadar MDA jantung didapatkan tidak terdapat perbedaan bermakna antar kelompok perlakuan $(p=0,133)$.

\section{Pemeriksaan kadar MDA plasma}

Terdapat perbedaan bermakna antara seluruh kelompok perlakuan dibanding kelompok normal $(p<0,05)$. Kelompok B, C dan D didapatkan kadar MDA dalam plasma lebih rendah secara bermakna dibanding kelompok $A(p<0,05)$. Kelompok $E$ dan $F$ menunjukkan kadar MDA yang lebih tinggi secara bermakna dibanding kelompok $A(p<0,05)$. Antar kelompok $B, C$

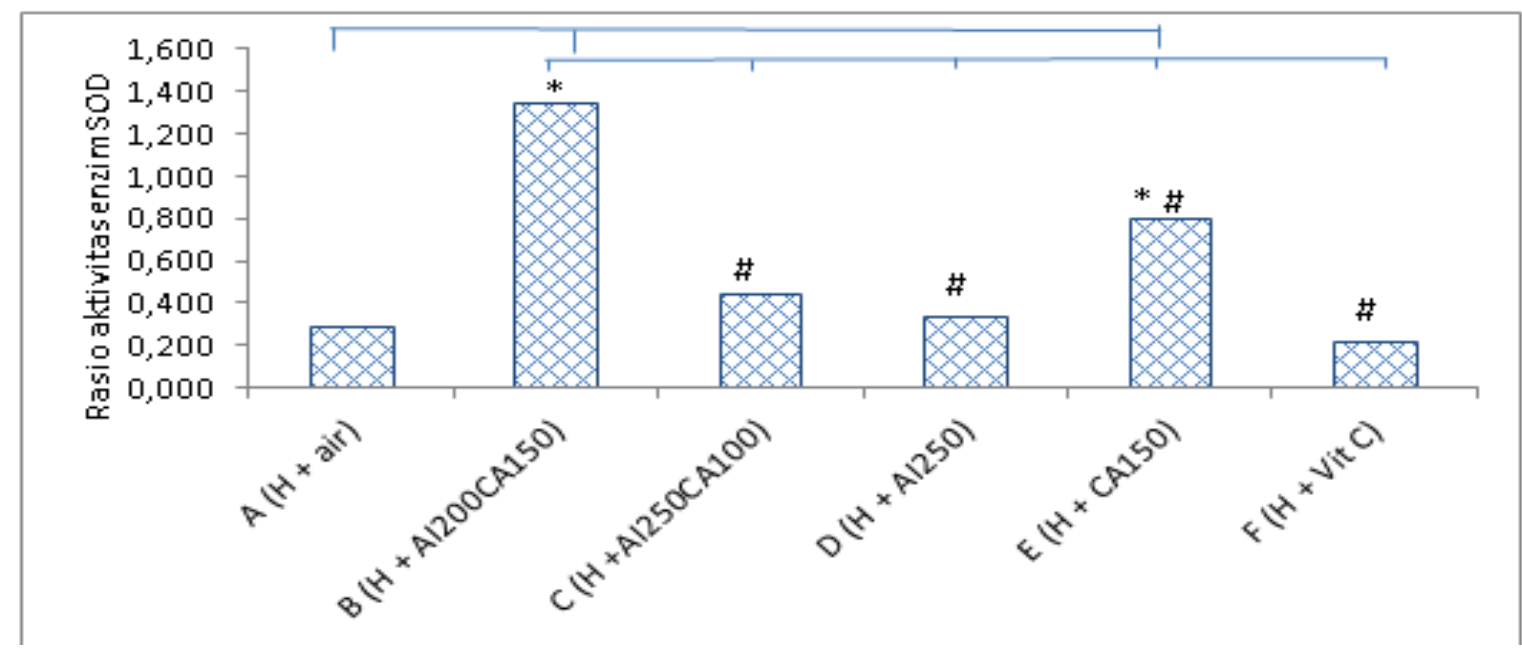

Gambar 3. Rasio kadar SOD jantung. Data disajikan sebagai rasio terhadap kontrol.

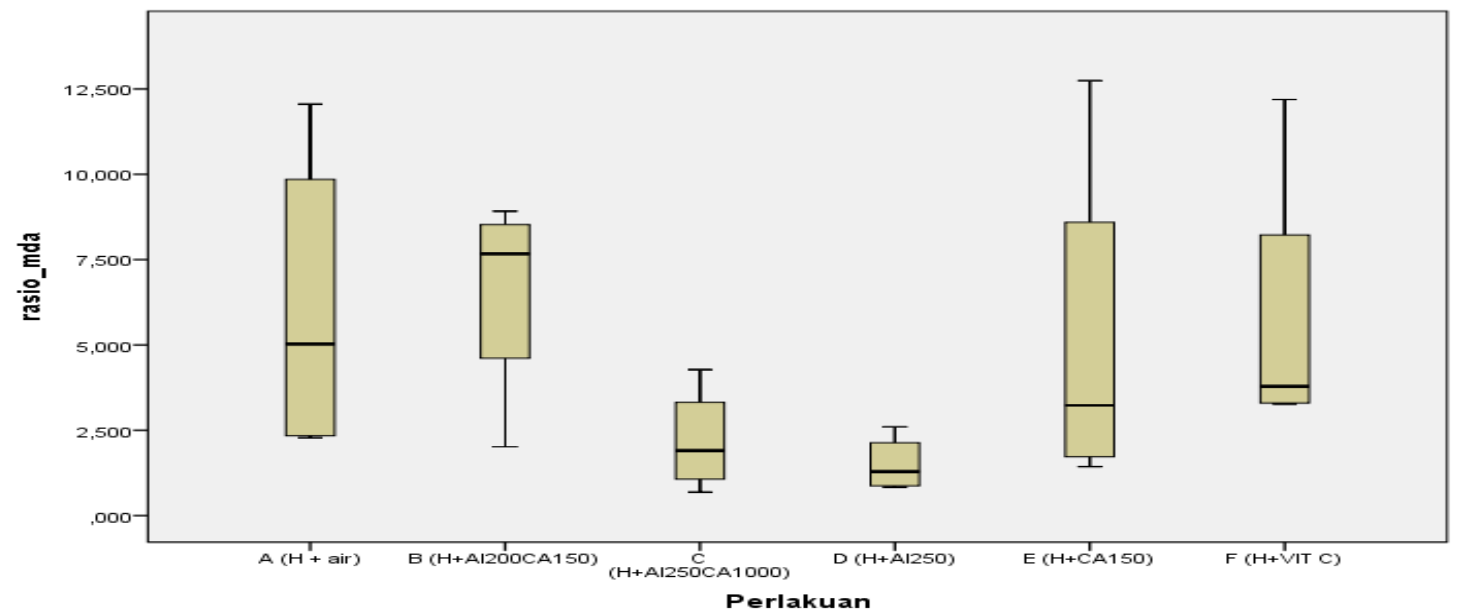

Gambar 4. Rasio kadar MDA jantung. Data disajikan sebagai rasio terhadap kontrol. 
dan $\mathrm{D}$ tidak didapatkan perbedaan yang bermakna $(p>0,05)$.

\section{Pemeriksaan ekspresi gen cardiac Troponin I (cTnl)}

Cardiac Troponin I telah digunakan secara luas sebagai penanda kerusakan miokardium. Untuk melihat perubahan ekspresi mRNA cTnl pada jantung tikus akibat hipoksia sistemik selama tujuh hari dan pengaruh pemberian kombinasi ekstrak etanol Acalypha indica dan Centella asiatica dilakukan pemeriksaan ekspresi mRNA cTnl dengan Real Time PCR. Hasil analisis statistik diperoleh pada pemberian perlakuan ekstrak tanaman Acalypha indica dan Centella asiatica kombinasi maupun tunggal serta pemberian vitamin $\mathrm{C}$ tidak memberikan perbedaan yang bermakna dibanding tikus hipoksia yang diberi air $(p>0,05)$. Terdapat peningkatan bermakna kelompok $D$,
E dan $\mathrm{F}$ dibanding kelompok B. Ekspresi cTnl pada kelompok $\mathrm{E}$ berbeda secara signifikan dibanding kelompok C.

\section{Pembahasan}

Model eksperimental yang dilakukan adalah dengan menginduksi hipoksia secara sistemik pada tikus selama 7 hari. Kondisi hipoksia telah dilakukan konfirmasi dengan pemeriksaan analisis gas darah. Tikus yang diinduksi hipoksia selama tujuh hari dan hanya diberi air didapatkan ekspresi HIF-1 $\alpha$ rendah. Hal ini disebabkan karena tikus dipindahkan ke kandang biasa untuk mendapatkan perlakuan. Dalam kandang normoksia, HIF-1 $\alpha$ akan terdegradasi oleh proteasom. Prolyl hydroxylase (PHD-2) dan von Hippel-Lindau tumor supresor ( $\mathrm{pVHL}$ ) adalah kompleks protein yang berperan dalam degradasi HIF-1 $\alpha$ (Septelia et al. 2009).

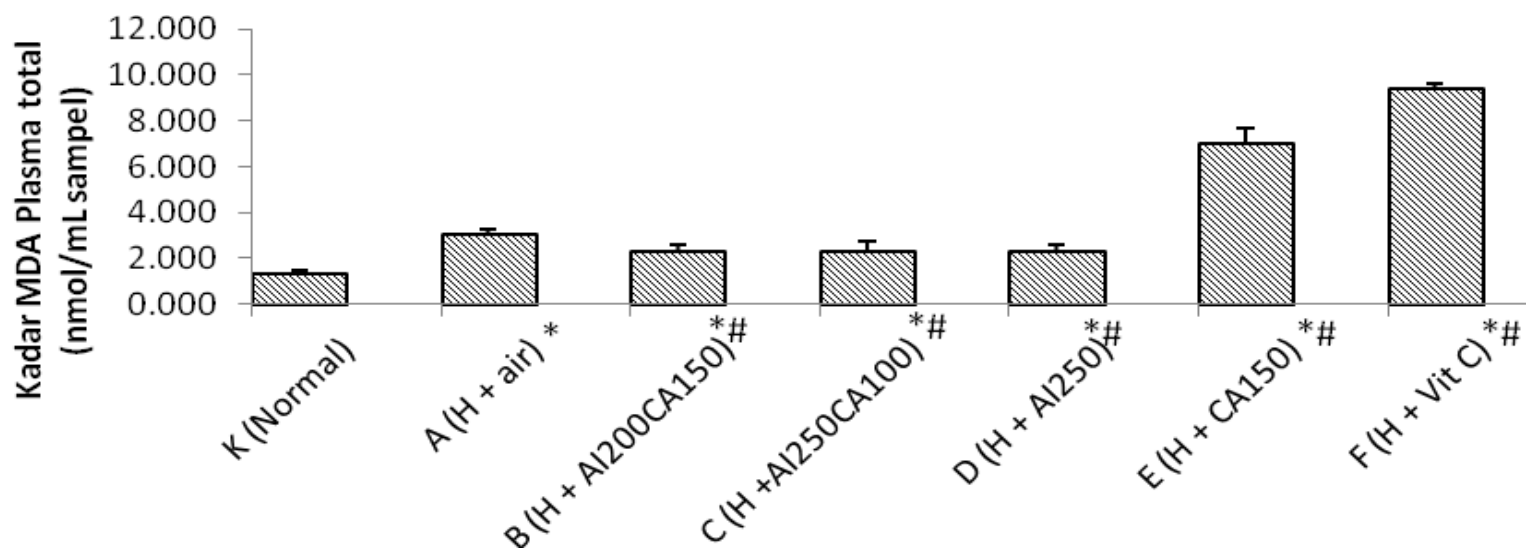

Gambar 5. Kadar MDA plasma tikus pascahipoksia. Data disajikan dalam nilai rerata. *) berbeda bermakna dibanding kelompok $\mathrm{K}$; \#) berbeda bermakna dibanding kelompok $\mathrm{A}$.

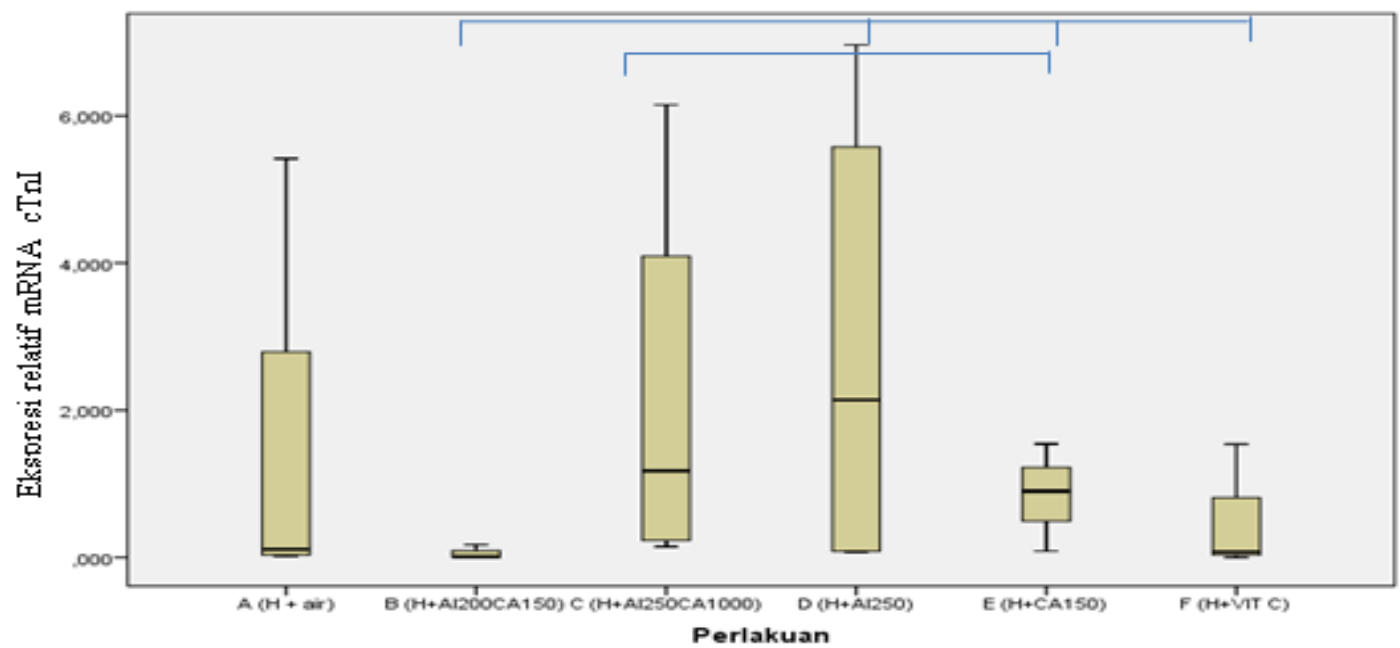

Gambar 6. Perubahan Ekspresi gen cTnl. Data disajikan sebagai nilai median dan grafik boxplot. Box (garis bawah : nilai min, garis tengah : median, garis atas : nilai max). 
Kelompok tikus yang diberikan perlakuan kombinasi ekstrak Acalypha indica dan Centella asiatica mengalami penurunan ekspresi HIF- $1 \alpha$ dibanding kelompok tikus hipoksia yang hanya diberi air. Pada kelompok kombinasi Acalypha indica $200 \mathrm{mg} / \mathrm{kg}$ dan Centella asiatica $150 \mathrm{mg} / \mathrm{kg}$ menunjukkan penurunan secara bermakna sedangkan kelompok kombinasi Acalypha indica $250 \mathrm{mg} / \mathrm{kg}$ dan Centella asiatica 100 $\mathrm{mg} / \mathrm{kg}$ menunjukkan penurunan yang tidak bermakna. Hal ini dapat disebabkan aktivitas antioksidan senyawa dalam tanaman tersebut. Jika ROS yang terbentuk dapat dinetralisasi sehingga enzim PHD akan bekerja secara optimal dan akan mengakibatkan degradasi HIF1 $\alpha$. Gambaran ini juga dapat diakibatkan kandungan flavonoid dalam tanaman tersebut karena telah dibuktikan oleh peneliti lain bahwa flavonoid dapat menghambat aktivitas HIF-1 $\alpha$ dengan merusak fosforilasi HIF-1 $\alpha$ tergantung MAPK sehingga menurunkan akumulasi HIF-1 $\alpha$ pada nucleus (Kohen et al. 2002). Pada pemberian ekstrak tunggal Acalypha indica atau Centella asiatica serta vitamin C didapatkan peningkatan ekspresi HIF-1 $\alpha$ secara tidak bermakna dibanding tikus hipoksia yang diberi air. Flavonoid telah terbukti dapat mengikat zat besi yang merupakan kofaktor enzim PHD pada kondisi normoksia sehingga menyebabkan akumulasi HIF-1 $\alpha$ (Alle 2012; Triantafyllou et al. 2008).

Peneliti lain yang memeriksa ekspresi mRNA HIF$1 \alpha$ pada organ ginjal didapatkan kelompok hipoksia diberi air lebih tinggi dibanding kelompok normal. Kelompok tikus yang diberi kombinasi ektrak didapatkan menurun secara signifikan dibanding kelompok hipoksia diberi air. Tidak terdapat perbedaan bermakna pada kelompok yang diberi ekstrak tunggal dan vitamin $\mathrm{C}$ dibanding kelompok hipoksia diberi air.

Kadar MDA plasma pada kelompok yang diinduksi hipoksia lebih tinggi secara signifikan dibanding kelompok tikus normal. Peningkatan kadar MDA ini diakibatkan oleh peningkatan jumlah ROS. Hipoksia meningkatkan pembentukan dan pelepasan ROS dari dalam mitokondria kemudian ROS bereaksi dengan membran sel yang terdiri atas poly unsaturated fatty acid disebut proses peroksidasi lipid. MDA merupakan hasil akhir peroksidasi lipid (Jusman 2010; Livak 2001; Richard et al. 2010). Peningkatan ROS dapat diatasi dengan sistem antioksidan endogen termasuk superoxide dismutase (SOD). SOD merupakan enzim yang berinteraksi langsung dengan ROS dan dapat melindungi sistem biologi. Enzim ini mampu melakukan dismutasi radikal superoksida menjadi $\mathrm{H}_{2} \mathrm{O}_{2}$ secara spontan. Produk reaksi dismutasi $\mathrm{H}_{2} \mathrm{O}_{2}$ dapat dibuang oleh aktivitas enzim katalase dan enzim peroksidase lain termasuk glutation peroksidase (Juswan 2010).

$$
\mathrm{O}_{2}^{\cdot-}+\mathrm{O}_{2}^{\cdot-} \stackrel{\mathrm{SOD}}{\longrightarrow} \mathrm{H}_{2} \mathrm{O}_{2}+\mathrm{O}_{2}
$$

Aktivitas kompensasi ini dapat melindungi PUFA sehingga molekul ini tidak mengalami oksidasi oleh radikal oksigen pada tahap hipoksia lebih lanjut (Enikarmila et al 2009 ). Pada penelitian ini rasio aktivitas enzim SOD pada kelompok tikus hipoksia yang diberi ekstrak kombinasi Acalypha indica 200 mg/kgBB dan Centella asiatica $150 \mathrm{mg} / \mathrm{kgBB}$ didapatkan lebih tinggi secara bermakna dibanding kelompok hipoksia yang hanya diberi air. Namun kondisi ini tidak dapat mengatasi peningkatan zat-zat oksidan dengan ditandai rasio kadar MDA jantung yang lebih tinggi yang tidak bermakna dibanding kelompok hipoksia yang hanya diberi air. Kadar MDA plasma tikus hipoksia dengan pemberian ekstrak kombinasi ini didapatkan lebih rendah secara bermakna dibanding kelompok hipoksia dan diberi air. Pemberian kombinasi ekstrak Acalypha indica $200 \mathrm{mg} / \mathrm{kgBB}$ dan Centella asiatica $150 \mathrm{mg} / \mathrm{kgBB}$ tidak dapat mengatasi peningkatan ROS pada miosit jantung. Hal ini dapat terjadi karena aktivitas antioksidan senyawa-senyawa dalam ektrak tanaman yaitu polifenol, flavonoid, $\beta$-karoten dan tannin, namun senyawa yang memiliki aktivitas antioksidan dapat membentuk prooksidan. Sesuai dengan penelitian Fukumoto dan Mazza (2000) yang meneliti aktivitas prooksidan pada ekstrak berry termasuk senyawa fenol yang memiliki aktivitas prooksidan pada konsentrasi rendah. Kondisi ini juga dapat terjadi karena campuran beberapa senyawa flavonoid selain dapat memberikan efek sinergistik juga dapat memberikan efek yang berlawanan. Seperti pada campuran flavonoid dari ekstrak Ginko biloba (EGb761) dengan pycnogenol (pyc) yang memiliki efek antioksidan tetapi tidak memberikan efek protektif pada aktivitas $\mathrm{Ca}^{2+}$-ATPase (Lubica 2011).

Pada pemberian kombinasi ekstrak Acalypha indica $250 \mathrm{mg} / \mathrm{kgBB}$ dan Centella asiatica $100 \mathrm{mg} / \mathrm{kgBB}$ dapat menurunkan kadar MDA plasma secara signifikan dibanding kelompok tikus hipoksia dan diberi air. Rasio MDA jantung lebih rendah yang tidak bermakna dan rasio aktivitas enzim SOD lebih tinggi yang tidak bermakna dibanding kelompok tikus hipoksia dan diberi air. Pemberian ekstrak tunggal Acalypha indica $250 \mathrm{mg} / \mathrm{kgBB}$ didapatkan rasio kadar MDA jantung

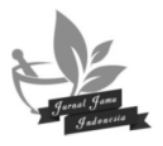


lebih rendah yang tidak bermakna dibanding kelompok tikus hipoksia sesuai dengan penurunan kadar MDA plasma namun peningkatan rasio aktivitas enzim SOD tidak terjadi secara signifikan. Hal ini sesuai dengan penelitian Matthew et al. (2011), yang mengukur peroksidasi lipid dan enzim SOD pada tikus yang diinduksi paracetamol dan diberi perlakuan ekstrak etanol Acalypha indica $100 \mathrm{mg} / \mathrm{kgBB}$ per oral selama 5 hari. Hasilnya didapatkan kadar MDA lebih rendah secara signifikan dibanding tikus yang tidak mendapat ekstrak Acalypha indica. Kondisi ini dapat terjadi karena aktivitas antioksidan senyawa-senyawa yang terdapat dalam tanaman tersebut. Telah banyak diteliti aktivitas Acalypha indica dan Centella asiatica sebagai antioksidan karena mengandung flavonoid dan fenol yang merupakan senyawa yang berperan sebagai antioksidan (Mijanur et al. 2013; Duangsuree et al. 2012; Durga et al. 2009; Rajeswara et al. 2011; Hashim 2011; Viswanatha et al. 2011).

Pada kelompok tikus yang diberikan ekstrak tunggal Centella asiatica $150 \mathrm{mg} / \mathrm{kgBB}$ didapatkan penurunan rasio kadar MDA homogenat jantung yang tidak bermakna dan peningkatan MDA plasma yang signifikan. Rasio aktivitas SOD lebih tinggi secara bermakna dibandingkan tikus hipoksia yang hanya diberi air.

Viswanatha et al. (2011), telah meneliti efek kardioprotektif asam askorbat pada tikus yang diinduksi doksoribisin dan didapatkan bahwa asam askorbat yang diberikan $20 \mathrm{mg} / \mathrm{kgBB}$ secara oral dapat melindungi miokardium dengan meningkatkan kadar antioksidan SOD, GSH, dan CAT dan menurunkan kadar MDA secara signifikan. Namun pada penelitian ini kelompok tikus hipoksia yang diberi vitamin C didapatkan rasio kadar MDA jantung lebih rendah yang tidak signifikan dan kadar MDA plasma lebih tinggi signifikan dibanding kelompok tikus hipoksia yang hanya diberi air, sedangkan aktivitas SOD lebih rendah yang tidak bermakna. Vitamin C secara umum berfungsi sebagai antioksidan, tetapi vitamin $C$ juga dapat membentuk prooksidan dengan mengubah radikal bebas menjadi hidrogen peroksida. Hidrogen peroksida dapat merusak membran sel dan DNA jika tidak dinetralisasi oleh enzim katalase. ${ }^{30}$ Vitamin C merupakan agen pereduksi kuat yang membentuk radikal askorbat sebagai pada proses oksidasi $\left(\mathrm{AscH}^{-}+\right.$ $\mathrm{X}^{--} \rightarrow \mathrm{Asc}^{{ }^{-}}+\mathrm{XH}$ ). Asc ${ }^{\circ-}$ memiliki elektron yang tidak berpasangan dan dapat membentuk superoksida pada level rendah. Asc ${ }^{\circ-}$ dapat direduksi kembali menjadi askorbat oleh sistem enzim. Terdapat variasi konsentrasi sehingga terjadi perubahan prooksidan menjadi antioksidan. Hal ini dapat dipengaruhi adanya logam katalis yang menginisiasi oksidasi rantai radikal (Garry \& Beth 1996). Kondisi hipoksia kemungkinan menyebabkan penurunan kemampuan enzim katalase dalam mengatasi prooksidan yang terbentuk oleh vitamin C.

Peneliti lain yang menguji organ ginjal dari penelitian utama didapatkan hasil bahwa kombinasi ekstrak Acalypha indica $250 \mathrm{mg} / \mathrm{kgBB}$ dan Centella asiatica $100 \mathrm{mg} / \mathrm{kgBB}$ serta ekstrak tunggal Acalypha indica $250 \mathrm{mg} / \mathrm{kgBB}$ dan Centella asiatica $150 \mathrm{mg} / \mathrm{kgBB}$ didapatkan kadar MDA homogenat ginjal menurun secara signifikan dibanding kelompok hipoksia yang hanya diberi air, sedangkan ekstrak kombinasi tanaman Acalypha indica $200 \mathrm{mg} / \mathrm{kgBB}$ dan Centella asiatica 150 $\mathrm{mg} / \mathrm{kgBB}$ didapatkan kadar MDA menurun tidak signifikan. Pemberian vitamin $C$ juga menyebabkan peningkatan MDA homogenat ginjal (Nurfitri 2015). Berbeda dengan kadar MDA homogenat hati, kadar MDA setelah pemberian ekstrak kombinasi Acalypha indica $200 \mathrm{mg} / \mathrm{kgBB}$ dan Centella asiatica $150 \mathrm{mg} / \mathrm{kgBB}$ didapatkan lebih rendah secara signifikan dibanding kelompok tikus hipoksia diberi air, sedangkan kelompok tikus yang diberikan ekstrak kombinasi Acalypha indica $250 \mathrm{mg} / \mathrm{kgBB}$ dan Centella asiatica 100 $\mathrm{mg} / \mathrm{kgBB}$ didapatkan MDA homogenat hati lebih tinggi dibanding kelompok hipoksia. Ekstrak tunggal Acalypha indica $200 \mathrm{mg} / \mathrm{kgBB}$ dan Centella asiatica $150 \mathrm{mg} / \mathrm{kgBB}$ serta vitamin $C$ dapat menurunkan kadar MDA hati tetapi tidak berbeda bermakna dibanding kelompok hipoksia yang diberi air (Agnes 2015). Variasi hasil pengukuran kadar MDA antar organ ini dapat disebabkan aliran darah dan kemampuan regenerasi masing-masing organ berbeda.

Cardiac troponin I merupakan protein yang dilepaskan ketika kardiomiosit mengalami kerusakan. Protein ini telah digunakan sebagai penanda kerusakan sel miokardium dengan sensitivitas tinggi (Xun et al. 2011). Jean et al. (1999), menginduksi tikus dengan hipoksia 60 menit kemudian direoksigenasi. Setelah induksi hipoksia selama 60 menit didapatkan konsentrasi cardiac troponin I dalam plasma meningkat signifikan dibanding pada kondisi normoksia.Jika terdapat kerusakan pada kardiomiosit troponin I akan meningkat dan bertahan selama 7-14 hari pada sirkulasi darah (Stillman et al. 2011). Pada penelitian ini tidak diukur cardiac troponin I pada plasma karena 
plasma telah digunakan untuk mengukur parameter oleh peneliti lain. Kelompok tikus yang diinduksi hipoksia selama 7 hari didapatkan ekspresi gen cTnl rendah. Hal ini dapat terjadi jika miosit jantung mengalami kerusakan troponin I dilepaskan ke sirkulasi darah atau mengalami degradasi. Stres oksidatif dapat menyebabkan perubahan homeostasis kalsium. Pada peningkatan konsentrasi kalsium, protease I yang diaktivasi kalsium (kalpain I) menjadi teraktivasi. Aktivasi kalpain I dapat merusak target protein termasuk troponin I. Troponin yang bertanggung jawab pada interaksi antara aktin dan miosin akan mengalami proteolisis oleh kalpain I sehingga menyebabkan kerusakan kontraksi dan relaksasi. ${ }^{37}$ Pemberian kombinasi ekstrak tanaman Acalypha indica 200 $\mathrm{mg} / \mathrm{kgBB}$ dan Centella asiatica $150 \mathrm{mg} / \mathrm{kgBB}$ serta pemberian ekstrak tunggal Centella asiatica 150 $\mathrm{mg} / \mathrm{kgBB}$ dan vitamin $\mathrm{C}$ didapatkan ekspresi mRNA cTnl lebih rendah tetapi tidak bermakna dibanding kelompok hipoksia diberi air $(p>0,05)$. Kondisi ini dapat terjadi karena efek antioksidan tersebut tidak mampu menetralisir ROS sehingga menyebabkan terjadinya kerusakan miosit jantung.

Pemberian kombinasi ekstrak tanaman Acalypha indica $250 \mathrm{mg} / \mathrm{kgBB}$ dan Centella asiatica $100 \mathrm{mg} / \mathrm{kgBB}$ serta ekstrak tunggal Acalypha indica $250 \mathrm{mg} / \mathrm{kgBB}$ didapatkan ekspresi mRNA cTnl lebih tinggi dibanding tikus hipoksia diberi air. Pada penelitian ini tikus mendapat induksi hipoksia selama 7 hari kemudian dipindahkan ke kandang normoksia untuk mendapat perlakuan, sehingga aktivitas antioksidan yang menetralisir ROS dan melindungi kardiomiosit dari kerusakan. Kondisi ini juga dapat terjadi karena hipoksia dapat mempengaruhi ekspresi cTnl. Karena HIF-1 $\alpha$ yang stabil pada kondisi hipoksia merupakan faktor transkripsi yang mengaktivasi ekspresi gen sebagai respon adaptif terhadap hipoksia.

\section{Simpulan}

Kesimpulan yang dapat diambil dari penelitian ini adalah pemberian kombinasi ekstrak etanol Acalypha indica $200 \mathrm{mg}$ dan Centella asiatica $150 \mathrm{mg}$ pada tikus Spraque-Dawley pascahipoksia dapat meningkatkan enzim Superoxide Dismutase (SOD) secara bermakna akibat kerusakan jaringan jantung dibandingkan pemberian kombinasi Acalypha indica $250 \mathrm{mg}$ dan Centella asiatica $100 \mathrm{mg}$ maupun ekstrak tunggal Acalypha indica $250 \mathrm{mg} / \mathrm{kgBB}$ atau Centella asiatica $150 \mathrm{mg} / \mathrm{kgBB}$. Pemberian kombinasi ekstrak etanol
Acalypha indica dan Centella asiatica pada tikus Spraque-Dawley pascahipoksia tidak dapat menurunkan produksi malondialdehid akibat kerusakan jaringan jantung pascahipoksia selama 7 hari. Pemberian kombinasi ekstrak etanol Acalypha indica dan Centella asiatica pada tikus Spraque-Dawley pascahipoksia tidak dapat menurunkan ekspresi mRNA HIF-1 $\alpha$ akibat kerusakan jaringan jantung. Pemberian kombinasi ekstrak etanol Acalypha indica dan Centella asiatica pada tikus Spraque-Dawley pascahipoksia tidak dapat meningkatkan ekspresi mRNA Troponin-I (cTnl) akibat kerusakan jaringan jantung.

\section{Saran}

Penelitian ini masih ada kekurangan dan memerlukan informasi yang lebih lengkap. Saran untuk penelitian selanjutnya adalah pemeriksaan HIF-1a dan cTnl segera setelah induksi hipoksia selama 7 hari untuk membandingkan sebelum dan sesudah perlakuan, perlu pemeriksaan untuk membandingkan ekspresi mRNA cTnl pada homogenat jantung dengan kadar troponin I dalam plasma, membandingkan ekspresi mRNA HIF-1a dengan protein HIF-1a dan perlu penelitian lebih lanjut terhadap kerusakan jantung secara histopatologi.

\section{Daftar Pustaka}

Agnes F. 2015. Kajian efek antioksidan kombinasi ekstrak etanol Acalypha Indica dan Centella Asiatica pada fungsi hati tikus Spraque-Dawley pascahipoksia sistemik [tesis]. Universitas Indonesia: Jakarta. Publ.in progress.

Aline B, Julia BS, Dieter S, Daniela F, Thomas K. 2010. The antioxidant quercetin inhibits cellular proliferation via HIF-1-dependent induction of p21WAF. Antioxidants \& Redox Signaling. 13(4):437-48.

Alle B. 2012. 1,25-dihydroxyvitamin D regulation of von Hippel-Lindau (VHL), prolyl hydroxylase 2 (PHD2) in MCF10A breast epithelial cells containing the Harvey-Ras-Oncogen [thesis] The College of Health and Human Sciences. Indiana (: Purdue University.

Anirban M, Sunanda M, Rituparna B, Anindita B. 2013. In vitro assay of antioxidant and antibacterial activity of leaf extract and leaf derived callus extract of Acalypha indica L. International Journal of Pharma Bio Sciences. 3(1):504-10. 
Bernhard B, Jie Z. 2007. Nitric oxide and superoxide: Interference with hypoxic signaling. Cardiovascular Research. 75:275-82.

Casciari JJ, Riordan NH, Schmidt TL, Meng XL, Jackson JA, Riordan HD. 2001. Cytotoxicity of ascorbate, lipoic acid, and other antioxidants in hollow fibre in vitro tumours. British Journal of Cancer. 84(11):1544-50.

Duangsuree S, Wirat N, Boonsom L, et al. 2012. Antioxidant and Anticancer Activities from Aerial Parts of Acalypha indica Linn. Journal of Natural Science. 11(2):157-68.

Durga KR, Karthikumar S, Jegatheesan K. 2009. Isolation of potential antibacterial and antioxidant compounds from Acalypha indica and Ocimum basilicum. Journal of Medicinal Plants Research. 3(10):703-6.

Enikarmila A, Indriati P, Ani RP, Septelia IW, Sri WAJ, Mohamad S. 2009. Malondialdehyde, reduced glutathione, and catalase activity of rat kidney tissue in chronic hypoxia. Majalah Kedokteran Indonesia. 59(12):596-600.

Farida S, Krisnamurti DGB, Sianipar I, Mudjihartini N. 2010. Efek neuroterapi kombinasi ekstrak akar kucing (Acalypha Indica L) dan pegagan (Centella asiatica $\mathrm{L}$ ) pada sel neuron tikus Sprague Dawley pascahipoksia. Forthcoming 2010.

Garry RB, Beth AJ. 1996. Catalytic, ascorbate and free radicals: Combinations to avoid. Radiation Research. 145:532-41.

Hashim P. 2011. Centella asiatica in food and beverage applications and its potential antioxidant and neuroprotective effect. International food Research Journal. 18(4): 1215-22.

Jean PB, Anne P, Emmanuelle R, Nadia S, Pascale FP, Sophie $P$, et al. 1999. Time course of cardiac troponin I release from isolated perfused rat hearts during hypoxia/reoxygenation and ischemia/reperfusion. Clinica Chimica Acta. 283:43-56.

Jusman SW. 2010. Respons jaringan hati terhadap hipoksia sistemik kronik : regulasi ekspresi gen sitoglobin oleh hypoxia-inducible factor-1a [disertasi]. Jakarta: Universitas Indonesia

Kohen R, Nyska A. 2002. Oxidation of biological system: Oxidative stress phenomena, antioxidant, redox reaction, and methods for their quantification. Toxicologic pathology. 30(6):620-650.
Livak KJ. 2001. Analysis of Relative Gene Expression Data Using Real-Time Quantitative PCR and the 2- $\Delta \Delta C T$ Method. Methods. 25:402-408

LR Fukumoto, G Mazza. 2000. Assesing antioxidant and prooxidant activities of phenolic Compounds. Journal Agriculture Food Chemistry. 48:3597-604.

Lubica H. 2011. Flavonoids in prevention of diseases with respect to modulation of Ca-pump function. Interdisciplinary Toxicology. 4(3):114-24.

Mathew M, Nair C, Sheoy T, Varghese J. 2011. Preventive and curative affects of Acalypha indica on acetaminophen-induced hepatotoxicity. International Journal of Green Pharmacy. 5:49-54.

Michael PM. 2009. How mitochondria produce reactive oxygen species. Biochemical Journal. 417:1-13.

Mijanur R, Hossain S, Rahaman A, Fatima N, Nahar T, Uddin B, et al. 2013. Antioxidant activity of Centella asiatica (Linn.) urban, impact of extraction solvent polarity. Journal of Pharmacognosy and Phytochemistry. 1(6):27-32.

Misra HP, Fridovich I. 1972. Substances of low molecular weight: The role of superoxide anion in the autoxidation of epinephrine and a simple assay for superoxide dismutase. The Journal of Biological Chemistry. 247:3170-5.

Nurfitri. 2015. Efek kombinasi ekstrak akar Acalypha Indica L. dan herba Centella Asiatica L. pada beberapa parameter biokimia dan histopatologi ginjal tikus Sprague-Dawley pascahipoksia [tesis]. Universitas Indonesia: Jakarta. Publ.in progress.

Pooja A, Malathi N, Chamudeeswari D, Dinesh MG. 2014. In vitro antioxidant activity of ethanolic extracts of Centella asiatica L, Oregano vulgare sub.sp hirtum and Ocimum basilicum L. Via five model systems. Indian Journal of Research in Pharmacy and Biotechnology. 2(3):1230-6.

Rajeswara RP, Venkatesh V, Sambasiva RE, Praneth VSP. 2011. Phytochemical investigation and in vitro anti oxidant, antimicrobial activity of different fractions of Acalypha Indica. International Journal of Pharmacy and Pharmaceutical Sciences. 3(4):314-7.

Richard M, Vinay K, Abul KA, Nelson F. 2010. Buku Saku Dasar Patologi Penyakit. 7th edition. Jakarta: EGC. Available in books.google.co.id/. Diunduh tanggal 7 Februari 2015.

Sanseera D, Niwatananun W, Liawruangrath B, Liawruangrath S, Baramee A, Trisuwan K, et al. 
2012. Antioxidant and anticancer activities from aerial parts of Acalypha indica Linn. Journal of Natural Sciences. 11(2):157-68.

Scott MW, Meg S. 2008. Cardiac troponin. Journal of Veterinary Emergency and Critical Care. 18(3):235-45.

Septelia IW, Syarifah D, Reni P. 2009. Ekspresi relative mRNA HIF-1a pada jantung, otak dan darah tikus selama induksi hipoksia sistemik. Makara. 13(2);185-8.

Shanmugapriya R, Ramathan T, Thirunavu P. 2011. Evaluation of antioxidant potential and antibacterial activity of Acalypha indica Linn. using in vitro model. Asian Journal of Biomedical and Pharmaceutical Sciences.

Stillman AE, Oudkerk M, Bremerich J, Esteves FP, Garcia EV, Gutberlet M, et al. 2011. Assessment of acute myocardial infarction: current status and recommendations from the North American Society for cardiovascular imaging and the European Society of Cardiac Radiology. The International Journal of Cardiovascular Imaging. 27:7-24.
Triantafyllou A, Mylonis I, Bonanou S, Tsakalof A. 2008. Flavonoid induce HIF-1alpha but impair its nuclear accumulation and activity. Free Radical Biology \& Medicine Journal. 44(4):657-70.

Van DL. 2002. Hypothesis: troponin degradation is one of the factors responsible for deterioration of left ventricular function in heart failure. Cardiovascular Research. 56:8-14.

Vasantharuba S, Banumathi P, Premalatha MR, Sundaram SP, Arumugam T. 2012. Functional properties of Centella asiatica (L.): A review. International Journal of Pharmacy \& Pharmaceutical Sciences. 4(5):8-14.

Viswanatha S, Wangikar U, Manjula DV. 2011. Cardioprotective effect of ascoric acid on doxorubicin induced myocardial toxicity in rats. Indian Journal of Pharmacology. 43(5):507-11.

Xun L, James T, Else ML, Suleiman MS. 2011. Marianne. Immediate hypothermia reduces cardiac troponin I following hypoxic-ischemic encephalopathy in newborn pigs. Pediatric Research. 70(4). 